\title{
PENEGAKAN HUKUM TERHADAP ALIH FUNGSI LAHAN PERTANIAN MENJADI LAHAN NON PERTANIAN DI KOTA MATARAM
}

\author{
LAW ENFORCEMENT ON CONVERSION OF AGRICULTURAL LAND \\ TO OTHER USES IN MATARAM
}

\author{
Baiq Burdatun \\ Fakultas Hukum Universitas Mataram \\ Email : baiqburdatun@gmail.com
}

Naskah diterima : 20/09/2016; revisi : 16/12/2016; disetujui : 30/12/2016

\begin{abstract}
Mataram City as a capital of West Nusa Tenggara Province has changed dramatically because it is focused as centre of economy/Mataram Metro. District Laws Number 12 the of 2011 in the implementation is not effective yet, as seen in the transfer of agricultural land function which is often completed without being able to be controlled. Economic incentive which is mentioned in the laws is still on normative level, so that it is relatively difficult to implement in the field. Therefore, much of productive agricultural land is changed to become non-agricultural land, on the other words as housing and office complex. Method of this research which is used in this article is empirical legal research. This article will explain about law enforcement in transfer of agricultural land to become non-agricultural land in Mataram City.
\end{abstract}

Keywords: Law Enforcement, Function Transfer, Agricultural Land

Abstrak

Kota Mataram sebagai ibu kota Propinsi Nusa Tenggara Barat (NTB) telah mengalami banyak perubahan yang secara dramatis karena Kota Mataram difokuskan sebagai pusat ekonomi dan jasa/ Mataram Metro. Perda Kota Mataram Nomor 12 Tahun 2011 dalam implementasinya belum efektif sebagaimana terlihat dari alih fungsi lahan pertanian yang terus terjadi dan semakin tidak terkendali. Insentif ekonomi yang tertuang dalam peraturan tersebut masih dalam tataran normatif, sehingga relatif sulit untuk diimplementasikan di lapangan. Oleh karena itu, banyak lahan pertanian yang produktif diubah menjadi lahan non-Pertanian atau dengan kata lain sebagai perkantoran dan perumahan. Jenis penelitian yang digunakan dalam artikel ini adalah penelitian hukum empiris. Artikel ini akan membahas banyak tentang penegakan hukum terhadap alih fungsi lahan pertanian menjadi lahan non pertanian di Kota Mataram. . penelitian empiris

Kata Kunci: Penegakan Hukum, Alih Fungsi, Lahan Pertanian

\section{PENDAHULUAN}

PEMERINTAH SELAKU pemegang hak penguasaan atas bumi, air, dan kekayaan alam yang terkandung di dalamnya sebagaimana tertuang di dalam Undang-Undang Dasar Negara Republik Indonesia Tahun 1945, Pasal 33 ayat (3), menentukan "bumi, air, dan kekayaan alam yang terkandung di dalamnya dikuasai oleh Negara dan dipergunakan sebesar-besarnya kemak- muran rakyat". Ketentuan ini menjadi landasan filosofis dan landasan yuridis bagi Negara Indonesia dalam rangka mengelola sumber daya alam (SDA) sekaligus mengatur hak-hak penguasaan dan pemanfaatan tanah, air dan ruang angkasa dengan prinsip kebersamaan, efisiensi, berkeadilan, berkelanjutan, berwawasan lingkungan. Negara Indonesia sebagai organisasi kekuasaan yang tertinggi seluruh 
rakyat Indonesia, dalam hal ini pemerintah Indonesia sebagai pengemban utama tanggungjawab memajukan kesejahteraan umum bagi rakyat Indonesia diberikan kewenangan oleh UUPA sebagai pemegang kekuasaan yang tertinggi atas bumi, air dan ruang angkasa, termasuk kekayaan alam yang terkandung di dalamnya sebagaimana yang tercermin di dalam ketentuan Pasal 2 ayat (1) UUPA, bahwa bumi, air dan ruang angkasa, termasuk kekayaan alam yang terkandung di dalamnya itu, pada tingkatan yang tertinggi "dikuasi" oleh Negara sebagai organisasi seluruh rakyat.

Hak menguasai Negara dimaksud adalah memberikan kewenangan kepada lembaga hukum dan hubungan hukum konkrit antara Negara dengan Tanah Indonesia. Kewenangan Negara tersebut merupakan pelimpahan tugas Bangsa, sehingga kewenangan tersebut semata-mata bersifat publik. Negara dalam hal ini bukan sebagai suatu badan hukum yang memiliki, akan tetapi Negara diberikan kewenangan untuk mengatur sebagaimana yang tercantum dalam Pasal 2 ayat (2) UUPA:

a. Mengatur dan menyelenggarakan peruntukkan, penggunaan, persediaan dan pemeliharaan bum, air dan ruang angkasa tersebut;

b. Menentukan dan mengatur hubunganhubungan hukum antara orang-orang dengan bumi, air dan ruang angkasa;

c. Mengatur dan menentukan hubunganhubungan hukum antara orang-orang dan perbuatan-perbuatan hukum yang mengenai bumi, air dan ruang angkasa.

Atas dasar kewenangan tersebut, maka Negara berkewajiban untuk mengatur penyediaan, peruntukan dan penggunaan bumi, air, ruang angkasa dengan sebaikbaiknya dengan mempertimbangkan prinsip keadilan, kepastian dan kemanfaatan nya. Kewenangan yang dimiliki oleh pemerintah pusat ataupun pemerintah daerah, dengan kata lain pemerintah tidak boleh melakukan suatu tindakan hukum apapun di luar kewenangan yang dimilikinya.

Hak menguasai dari negara atas tanah bersumber pada hak bangsa Indonesia atas tanah, yang hakikatnya merupakan penugasan pelaksanaan tugas kewenangan bangsa yang mengandung unsur publik. Tugas mengelola seluruh tanah bersama tidak mungkin dilaksanakan sendiri oleh seluruh bangsa indonesia, maka dalam penyelenggaraannya, bangsa Indonesia sebagai pemegang hak dan pengemban amanat tersebut, pada tingkatan tertinggi dikuasakan kepada Negara Republik Indonesia sebagai organisasi kekuasaan seluruh rakyat (Pasal 2 ayat (1) UUPA).

Tanah merupakan salah satu sumber daya alam yang jumlahnya relatif tetap dan tidak mungkin bertambah, maka pengaturan dan pengendalian dalam penggunaan tanah (lahan) sangat diperlukan. Pengaturan dan pengendalian dalam penggunaan tanah bertujuan agar perubahan penggunaan tanah dapat terkendali khususnya dalam perubahan penggunaan fungsi lahan pertanian ke non pertanian. Persoalan tanah ataulahan khususnya yang berkaitan dengan alih fungsi, sudah terbukti menimbulkan dampak yang sangat merugikan bagi masyarakat seperti halnya yang terjadi dalam alih fungsi lahan pertanian dan lahan serapan air untuk fungsi perumahan dan peruntukan lainnya. Secara umum alih fungsi lahan sawah pertanian dari tahun ke tahun mencapai ratusan ribu hektar.

Alih fungsi lahan hampir terjadi di seluruh wilayah Provinsi, Kabupaten/ Kota di seluruh Indonesia tidak terkecuali di Kota Mataram yang penduduknya terus bertambah dan perkembangan pembangunan yang terus meningkat akan berdampak pada perubahan alih fungsi tanah. Pertumbuhan penduduk yang begitu cepat, serta intensitas pembangunan yang berkembang dalam berbagai bidang juga 
menyebabkan meningkatnya kebutuhan lahan, sehingga lahan pertanian produktif akan dimanfaatkan untuk pembangunan perumahan, industri, jalan raya, olah raga, fasilitas penunjang pariwisata seperti hotel, villa, home stay dan lain-lain.

Pembahasan dan penanganan masalah alih fungsi lahan pertanian yang dapat mengurangi jumlah lahan pertanian terutama lahan sawah telah berlangsung lama. Sampai saat ini pengendalian alih fungsi lahan pertanian memerlukan kebijakan yang dapat menyelesaikan secara fundamental terkait adanya sejumlah kebijakan yang objek pengaturannya adalah tanah. Pengendalian alih fungsi lahan pertanian, dan upaya perlindungan lahan pertanian produktif serta perlindungan terhadappetanimerupakansalahsatubentuk kebijakan yang strategis guna mewujudkan sistem pertanian yang berkelanjutan serta ketahanan, kemandirian dan kedaulatan pangan. Dalam konteks ini, pencegahan alih fungsi lahan sawah beririgasi di tingkat daerah perlu dipayungi secara yuridis dan disertai dengan penegakan hukumnya yang dalam hal ini sekaligus diperlukan kelembagaan Penyidik Pegawai Negeri Sipil di daerah. Pemerintah daerah seharusnya melakukan kegiatan mendorong penegakan hukum untuk mencegah alih fungsi lahan pertanian khususnya yang berkaitan dengan pemanfaatan irigasi.

Menurut Soerjono Soekanto, bahwa: ${ }^{1}$

"Inti dan arti dari penegakan hukum terletak pada kegiatan menyerasikan hubungan nilai-nilai yang terjabarkan dalam kaidah-kaidah yang mantap dan mengejawantah dan sikap tindak sebagai rangkaian penjabatan nilai tahap terakhir, untuk menciptakan, memelihara dan mempertahankan kedamaian pergaulan hidup."

${ }^{1}$ Soerjono Soekanto, Faktor-faktor yang Mempengaruhi Penegakan Hukum, Jakarta, PT RajaGrafindo Persada, 2011, hlm. 8.
Pentingnya "keserasian" oleh Soerjono Soekanto ini maka, pokok penegakan hukum sebenarnya terletak pada faktorfaktor yang mungkin mempengaruhinya. Oleh Soerjono Soekanto menyebutkan 5 (lima) faktor efektifitas hukum, yaitu: ${ }^{2}$

1) Faktor hukumnya sendiri, yaitu dalam teori ini dibatasi dengan undang-undang saja;

2) Faktorpenegakhukum,yaknipihak-pihak yang membentuk maupun menerapkan hukum;

3) Faktor sarana dan fasilitas yang mendukung penegakan hukum;

4) Faktor masyarakat, yakni lingkungan dimana hukum tersebut berlaku atau diterapkan;

5) Faktor kebudayaan, yakni mengenai hasil karya, cipta, danrasayangdidasarkanpada karsa manusia di dalam pergaulan hidup.

Lawrance M. Friedman mengemukakan bahwa efektif dan berhasil tidaknya penegakan hukum tergantung tiga unsur sistem hukum, yakni struktur hukum (struktur of law), substansi hukum (substance of the law) dan budaya hukum (legal cultere). Struktur hukum menyangkut aparat penegak hukum, substansi hukum meliputi perangkat perundang-undangan dan budaya hukum merupakan hukum yang hidup (living law) yang dianut dalam suatu masyarakat ${ }^{3}$

Untuk itu, Pemerintah kota Mataram dalam melaksanakan alih fungsi lahan pertanian menjadi lahan non pertanian tentunya harus mengedepankan prinsipprinsip serta tujuan yang tertuang di dalam UUD NRI Tahun 1945, Undang-Undang Nomor 5 Tahun 1960 (UUPA), UndangUndang Nomor 26 Tahun 2007 tentang Penataan Ruang, PP Nomor 16 Tahun 2004

\footnotetext{
${ }^{2}$ Ibid.

${ }^{3}$ Lawrance M. Friedman, Sistem Hukum Perspektif Ilmu Sosial, Jakarta, Nusamedia, 1984, hlm. 2.
} 
tentang Penata gunaan Tanah dan Perda Nomor 12 Tahun 2011 tentang RTRW kota Mataram sebagai pedoman dalam pengendalian dan pengawasan pemanfaatan sumber daya alam yakni tanah pertanian, serta untuk mensejahterakan kehidupan sosial dan menciptakan rasa keadilan bagi masyarakat kota Mataram.

Berdasarkan uraian di atas, maka penulis mencoba merumuskan beberapa permasalahan yaitu : Bagaimana kebijakan pemerintah kota Mataram dalam melaksanakan alih fungsi lahan pertanian menjadi lahan non pertanian?; Bagaimana mekanisme pelaksanaan alih fungsi lahan pertanian menjadi lahan non pertanian di kota Mataram?: Bagaimana penegakan hukum dalam pelaksanaan alih fungsi lahan pertanian di kota Mataram?

Tipe penelitian yang digunakan dalam memecahkan permasalahan penelitian ini adalah dengan meneliti hukum normatif-empiris, yaitu penggabungan antara pendekatan hukum normatif dengan adanya penambahan berbagai unsur empiris. Penelitian hukum normatif-empiris terhadap penegakan hukum alih fungsi lahan pertanian menjadi lahan non pertanian di kota Mataram adalah untuk mencari bagaimana implementasi ketentuan hukum normatif (undang-undang) dalam aksinya pada setiap peristiwa hukum tertentu yang terjadi di kota Mataram khususnya dalam hal alih fungsi tanah pertanian. Pembahasan

\section{A. Kebijakan Pemerintah Kota Mataram Dalam Melaksanakan Alih Fungsi La- han Pertanian Menjadi Lahan Non Pertanian}

Di bidang tata ruang, untuk melaksanakan ketentuan-ketentuan Undangundang Penataan Ruang, khususnya mengenai tata ruang wilayah Provinsi dan Kabupaten/Kota, maka di masing-masing Provinsi dan Kabupaten/Kota membentuk Peraturan Daerah tentang Rencana Pena- taan Ruang Daerah. Masing-masing daerah membuat rencana tata ruang sesuai dengan visi dan misi daerahnya serta ciri dan daya dukung sember daya alam setempat. Seperti di wilayah NTB sekarang prioritas pembangunannya adalah di bidang Peternakan (program sejuta sapi), dan di bidang pertanian (produksi jagung) serta di bidang perikanan dan kelautan (rumput laut). Oleh karenanya, maka rencana tata ruang NTB akan berorientasi pada penentuan lokasi yang cocok dan tepat untuk pengembangan ketiga komoditi tersebut dengan memperhatikan daya dukung sumber daya alam dan pelestarian lingkungan. ${ }^{4}$

Konsep kebijakan di bidang agraria seringkali sangat menarik pada tingkatan abstrak tetapi justru pada tingkatan implementasi menjadi hal yang sebaliknya. Misalnya konsep hak menguasai negara yang konon diangkat dari khazanah hukum adat yaitu hak ulayat yang menggambarkan kehendak yang kuat untuk mewujudkan hukum agraria nasional yang berakar dari hukum asli Indonesia, sehingga secara filosofis mendapatkan tempat pembenaran nya.

Konsep - konsep kebijakan yang melatarbelakangi masalah dalam ketimpangan struktur dan sengketa penguasaan tanah serta pengelolaan sumber daya alam lainnya telah menimbulkan berbagai persoalan agraria. Setiap konsep kebijakan merupakan jawaban yang dianggap paling tepat untuk menyelesaikan permasalahan yang sedang dihadapi, karena kebijakan merupakan pilihan dari beberapa pilihan yang ada, sesuai dengan pertimbangan dari unsur (unsur-unsur) yang paling dominan sehingga dijatuhkan nya pilihan kebijakan demikian.

Konsep kebijakan yang melatarbelakangi ketimpangan struktur penguasaan tanah

${ }^{4}$ H. M. Arba, Hukum Tata Ruang dan Tata Guna Tanah, Prinsip-Prinsip Hukum Perencanaan Penataan Ruang dan Penatagunaan Tanah, Cetakan II, Mataram, Pustaka Bangsa, 2015, hlm. 18. 
dan melahirkan sengketa tanah serta sumber daya alam lainnya harus diubah mengarah pada konsep kebijakan yang berorientasi kerakyatan, mengedepankan keadilan, bersifat integratif, berkelanjutan dan lestari dalam pengelolaannya. Konsep demikian tentunya masih sangat abstrak dan seharusnya diikuti oleh bentuknya yang lebih praktis, yang dalam keadaan nyata tidak bisa lepas dari interaksi dengan konsep-konsep di bidang lain misalnya politik, ekonomi, sosial budaya yang saling mempengaruhi satu dengan lainnya. ${ }^{5}$

Hal itu perlu menjadi catatan oleh karena pilihan kebijakan yang berorientasi kerakyatan mendapat tantangan dari konsep ekonomi pasar yang berorientasi pada kepentingan modal besar, yang pada ujungnya keuntungannya hanya dinikmati oleh segelintir orang. Juga ketergantungan ekonomi pada modal besar (investasi) sangat memberikan kemudahan dan fasilitas yang lebih berorientasi kepentingan pemodal daripada kepentingan rakyat banyak dan sebaliknya merugikan kepentingan rakyat banyak. Kontrol yang tidak efektif terhadap penyelewengan yang ditopang oleh budaya korup birokrasi semakin menambah kerugian negara.

Ekawati mengatakan bahwa pengertian kebijakan mempunyai beberapa implikasi, yaitu sebagai berikut: ${ }^{6}$

a. Bahwa kebijakan negara itu dalam bentuk perdananya berupa tindakantindakan dari pemerintah.

b. Bahwakebijakannegaraitutidakcukup hanya dinyatakan, tetapi dilaksanakan dalam bentuk yang nyata.

c. Bahwa kebijakan negara itu, baik untuk melakukan sesuatu maupun tindakan untuk melakukan sesuatu,

\footnotetext{
${ }^{5}$ Achmad Sodiki dan Yanis Maladi, Politik Hukum Agraria, Yogyakarta, Mahkota Kata, 2009, hlm. 64.

${ }^{6}$ Mas Roro Liliek Ekawati, Perencanaan, Implementasi dan Evaluasi Kebijakan atau Program (Suatu Kajian Teoritis dan Praktis), Surakarta, Pustaka Cakra, 2005, hlm. 12.
}

itu mempunyai dan dilandasi dengan maksud dan tujuan tertentu.

d. Bahwa kebijakan itu harus senantiasa ditujukan bagi kepentingan seluruh anggota masyarakat.

Kebijakan itu dibuat oleh pemerintah, kemudian dituangkan dalam tindakan -tindakan nyata, dengan tujuan untuk melayani kepentingan umum, berdasarkan prosedur yang berlaku dan didorong oleh keinginan untuk menghindari pertentangan yang destruktif. Kebijakan merupakan sarana bagi pemerintah untuk melaksanakan ketentuan-ketentan peraturan perundang-undangan yang lebih tinggi. Kebijakan pemerintah dalam melaksanakan perundang-undangan dapat dituangkan dalam bentuk Peraturan Pemerintah, Peraturan Presiden, Peraturan Menteri yang dikeluarkan oleh pemerintah pusat dan dalam bentuk Peraturan Daerah dan Keputusan Kepala Daerah yang dibuat oleh pemerintah daerah. Kebijakan pada umumnya untuk melaksanakan ketentuanketentuan hukum dalam melaksanakan kepentingan publik.

Kebijakan pemerintah Kota Mataram terkait dengan Rencana Pembangunan Jangka Panjang Daerah (RPJPD) Kota Mataram harus disusun sebagai penjabatan dan visi, misi, dan program Kepala Daerah untuk kurun waktu lima tahun yang penyusunannya berpedoman pada RPJP Daerah dan memperhatikan RPJM Nasional. RPJPD Kota Mataram disusun berdasarkan analisis permasalahan pembangunan dan isu-isu srtategis daerah, tujuan dan sasaran pembangunan daerah, strategi dan arah kebijakan pembangunan daerah, indikator sasaran dan target pencapaian pembangunan daerah yang bertumpu pada program pembangunan daerah lengkap dengan kerangka pendanaan serta kaidah pelaksanaannya.

Penyusunan RPJMD Kota Mataram akan mempengaruhi perencanaan tata ruang 
kota. Visi dan misi walikota terpilih akan diterjemahkan dalam perencanaan spasial. Sehubungan dengan penyusunan RPJMD maka Rencana Tata Ruang Wilayah (RTRW) Kota Mataram yang sedang disusun saat ini harus diselaraskan dengan dokumen RPJMD. Hal ini dimaksudkan agar keselarasan perencanaan pembangunan lima tahun mendatang sesuai dengan rencana penataan ruang wilayah.

Dalam RTRW Nasional, Kota Mataram ditetapkan sebagai Pusat Kegiatan Nasional (PKN) yang berfungsi sebagai pintu gerbang dan simpul utama transportasi serta kegiatan perdagangan dan jasa skala regional. Sementara, dalam RTRW Provinsi NTB, kota Mataram ditetapkan sebagai Kawasan Startegis Provinsi (KSP) Mataram Metro di bidang pertumbuhan ekonomi. Keberadaan kota Mataram sebagai PKN dan KSP memiliki potensi yang sangat strategis dalam pengembangan wilayah kota. Secara kewilayahan Kota Mataram dibagi menjadi beberapa pusat pelayanan dengan fungsi utama adalah:

1. WilayahAmpenanberfungsisebagaipusat pelayanan bagi kegiatan perdagangan dan jasa serta pariwisata;

2. Wilayah Mataram berfungsi sebagai pusat pelayanan bagi kegiatan perkantoran pemerintahan dan fasilitas sosial, seperti pendidikan;

3. Wilayah Cakranegara berfungsi sebagai pusat pelayanan bagi kegiatan perdagangan dan pusat bisnis.

Kota Mataram memiliki beberapa kawasan strategis yang diharapkan mampu untuk mendorong pertumbuhan wilayah dan memiliki pengaruh yang sangat penting dan strategis terhadap pertumbuhan dan perkembangan wilayah baik dalam bidang ekonomi, sosial-budaya, dan/atau lingkungan. Kawasan startegis wilayah kota berfungsi sebagai berikut:
1. Mengembangkan, melestarikan, melindungi, dan/atau mengkoordinasikan keterpaduan pembangunan nilai strategis kawasan yang bersangkutan dalam mendukung penataan ruang wilayah kota;

2. Sebagai alokasi ruang untuk berbagai kegiatan pertumbuhan ekonomi, sosial dan budaya, serta fungsi dan daya dukung lingkungan hidup dalam wilayah kota yang dinilai mempunyai pengaruh sangat penting terhadap wilayah kota bersangkutan;

3. Sebagai pertimbangan dalam penyusunan indikasi program utama RTRW kota, dan;

4. Sebagai dasar penyusunan rencana rinci tata ruang wilayah kota.

Ruang wilayah kota Mataram merupa kan pusat pemerintahan, pusat pendidikan, pusat perekonomian, serta pusat pengembangan barang dan jasa. Secara administratif kota Mataram memiliki luas daratan 61,30 kilometer persegi dan 56,80 kilometer persegi perairan. Bahwa dengan dengan adanya Undang-Undang Nomor 26 Tahun 2007 tentang Penataan Ruang, Peraturan Pemerintah Nomor 26 Tahun 2008 tentang Rencana Tata Ruang Wilayah Nasional, dan Peraturan Daerah Provinsi Nusa Tenggara Barat Nomor 3 Tahun 2010 tentang Rencana Tata Ruang Wilayah Provinsi Nusa Tenggara Barat, maka kebijakan dan strategi pemanfaatan ruang wilayah nasional perlu dijabarkan ke dalam rencana Tata Ruang Wilayah Kota Mataram. Maka atas dasar-dasar ketentuan tersebut ditetapkan suatu kebijakan daerah kota Mataram tentang Rencana Tata Ruang Wilayah Kota Mataram.

Tata Ruang Kota Mataram diatur dalam Peraturan Daerah Kota Mataram Nomor 12 Tahun 2011 mengenai Rencana Tata Ruang Wilayah Kota Mataram, dimana dalam penataan ruang Kota Mataram mempunyai tujuan yang hendak dicapai, yaitu: 
1. Terselenggaranya pemanfaatan ruang wilayah yang berkelanjutan dan berwawasan lingkungan sesuai dengan kemampuan daya dukung dan daya tampung lingkungan hidup serta kebijaksanaan pembangunan nasional dan daerah.

2. Terselenggaranya pengaturan pemanfaatan ruang kawasan lindung dan kawasan budidaya di kawasan perkotaan, kawasan pedesaan.

3. Terwujudnya keterpaduan dalam penggunaansumberdayaalamdansumber daya buatan dengan memperhatikan sumber daya manusia.

Terkait dengan wilayah pengembangan kawasan pertanian di Kota Mataram dalam Pasal 46 menentukan:

(1) Pengembangan kawasan pertanian sebagaimana dimaksud Pasal 33 ayat (1) huruf $m$, terdiri dari kawasan peruntukan pertanian dan kawasan peruntukan perikanan.

(2) Rencana pengembangan kawasan pertanian sebagaimana dimaksud ayat (1) dilakukan melalui:

a. Pengembangan lahan pertanian untuk budaya hortikultura;

b. Pengembangan lahan pertanian basah untuk peningkatan ketahanan pangan;

c. Membatasi alih fungsi lahan pertanian irigasi teknis untuk kegiatan budaya terbangun

d. Mempertahankan jaringan prasarana irigasi di kawasan pertanian yang disesuaikan dengan kebutuhan dan kondisi geografis;

e. Inventarisasi lahan dan pemilik lahan pertanian serta potensi kebutuhan air baku bagi pertanian.
(3) Pengembangan lahan pertanian untuk budidaya untuk tanaman hortikultura sebagaimana dimaksud pada ayat (2) huruf a, dilakukan di Kelurahan Rembiga, kelurahan Sayangsayang, Kelurahan Selagalas, Kelurahan Bertais, Kelurahan Mandalika, Kelurahan Jempong Baru, dan Kelurahan Turida.

(4) Rencana pengembangan kawasan perikanan sebagaimana dimaksud pada ayat (1), dilakukan melalui:

a. Pengembangan budidaya perikanan air tawar di Kelurahan Sayang-sayang, Kelurahan Selagalas, dan Kelurahan Bertais;

b. Pengembangan perikanan tangkap dan perikanan budidaya air laut di Kelurahan Bintaro, Kelurahan Ampenan Tengah, Kelurahan Banjar, Kelurahan Ampenan Selatan, Kelurahan Tanjung Karang Permai, Kelurahan Tanjung Karang, dan Kelurahan Jempong Baru: dan

c. Menyediakankawasanpenyanggapada kawasan perikanan.

Selanjutnya dalam Pasal 83 Ketentuan umum peraturan zonasi kawasan pertanian sebagaimana dimaksud dalam Pasal 70 huruf $m$ tentang ketentuan umum peraturan zonasi kawasan pertanian dilakukan dengan ketentuan sebagai berikut:

a. Dilakukan penggunaan kawasan pertanian untuk kegiatan pertanian dan perikanan;

b. Dikendalikan untuk penggunaan pendukung kegiatan pertanian dan perikanan; dan

c. Dilarang untuk penggunaan yang dapat memicu terjadinya pengembangan bangunan yang mengurangi luas ruang kawasan peruntukan pertanian.

Berdasarkan penjelasan Pasal di atas, terlihat dengan jelas bahwa Perda RTRW 
Kota mataram memberikan perlindungan terhadap keberadaan lahan pertanian dengan menentukan zonasi khusus lahan pertanian di kota mataram. Lahan pertanian begitu penting bagi kehidupan masyarakat khususnya kota mataram, oleh itu sangat disayangkan begitu maraknya terjadi alih fungsi lahan di Kota Mataram.

Di tengah kondisi yang semakin krodit ini, DPRD Kota Mataram bersama eksekutif akan melakukan revisi terhadap perda RTRW. Wakil walikota Mataram H Mohan Roliskana menegaskan ${ }^{7}$ rencana revisi perda RTRW bukan untuk mengesahkan pelanggaran yang sudah ada. Tapi bertujuan membangun tata ruang kota yang lebih baik. Ia mengatakan, revisi dilakukan karena pemerintah juga mempertimbangkan kondisi di tengah masyarakat. Dengan wilayah kota yang tidak terlalu luas, sementara populasi sangat tinggi, hal ini dikhawatirkan akan menimbulkan persoalan sosial kedepannya. Revisi RTRW yang akan dibuat ini diharapkan akan mengakomodasi, memproyeksikan persoalan yang akan dihadapi di masa depan. Mohan mengakui, perlu ada keseimbangan tata ruang kota agar tidak semakin disesaki bangunan. Untuk itu, ruang terbuka hijau sangat dibutuhkan agar orang merasa nyaman tinggal. Tapi untuk mencapai target 30 persen RTH menurutnya cukup sulit. Sebab sebagian besar lahan sudah dikuasai pengusaha.

Ketika ada alih fungsi lahan, maka ruang hijau akan terus berkurang. Meski demikian, pemerintah akan terus berupaya dengan meningkatkan kualitas RTH yang sudah ada. Ia menegaskan, target utama revisi RTRW ini adalah untuk membuat keseimbangan ekologis di kota Mataram. Di satu sisi tingkat pertumbuhan sangat cepat. Tapi ia juga tidak ingin investasi mengorbankan ruang terbuka hijau. Mohan mengakui, saat ini dampak lingkungan sudah mulai dirasakan masyarakat.

\footnotetext{
${ }^{7}$ Mohan Roliskana, "Selamatkan RTH atau Karpet Merah Pengusaha," Lombok Post, 5 Agustus 2016
}

Masyarakat sangat kekurangan ruang-ruang terbuka yang bisa dinikmati secara leluasa. Maka untuk mewujudkan semua itu, satusatunya jalan saat ini adalah dengan merevisi Perda RTRW. Hal ini akan menjadi dasar hukum bagi pemerintah untuk mengatur pembangunan. Jika tidak diatur, pemerintah sulit melarang pengusaha membangun. Mohan membantah pemerintah dianggap terlalu lunak kepada pengusaha. Semua keputusan yang diambil pemerintah tidak mungkin akan keluar daripada aturan. Menurutnya, yang sekarang terjadi sudah sesuai koridor hukum. Meski ada kritikan yang menganggap pemerintah lunak ia menegaskan hal itu tidak terjadi. Jadi pemerintah menjalankan tugas berdasarkan ketentuan peraturan. Rencana revisi Perda RTRW ini akan dilakukan pada masa sidang DPRD Kota Mataram berikutnya. Eksekutif dan legislatif sudah sepakat untuk melakukan revisi, sebab perda ini sudah berjalan lima tahun sehingga bisa ditinjau kembali dengan kondisi saat ini. Selama lima tahun, perjalanan Perda RTRW masih memiliki hutang yakni belum memiliki rencana detail tata ruang. Padahal sejak terbit 2011 lalu, rencana detail ini sudah disusun, tapi sampai lima tahun rencana detail ini menguap. Tidak pernah ada kejelasan kapan akan disahkan.

\section{B. Mekanisme Pelaksanaan Alih Fungsi Lahan Pertanian Menjadi Lahan Non Pertanian Di kota Mataram}

Pemerintah mempunyai tugas dan tanggungjawab untuk mengusahakan kesejahteraan bagi warganya. Sejak itu negara turut serta secara aktif dalam pergaulan kemasyarakatan, sehingga lapangan pekerjaan pemerintah makin lama makin luas. Administrasi negara diserahi tugas untuk menyelenggarakan kesejahteraan umum dengan cara ikut serta secara aktif dalam berbagai kehidupan rakyatnya di bidang ekonomi, sosial, budaya, medis, perpajakan dan sebagainya. Peran pemerintah dalam berbagai kegiatan 
masyarakat semakin nyata. Salah satu campur tangan pemerintah terhadap aktivitas masyarakat yang begitu terasa dalam hal ini adalah melalui instrumen perizinan. Melalui perizinan pemerintah mencampuri, mengarahkan, mengendalikan berbagai aktivitas dan sepak terjang warganya. ${ }^{8}$

Izin merupakan instrument hukum administrasi negara yang paling sering digunakan pemerintah dalam mengendalikan tingkah laku warganya. Izin dipandang dapat mengendalikan setiap usaha dan/ atau kegiatan yang berpotensi menimbulkan dampak pencemaran dan kerusakan lingkungan, hal ini didasarkan pada esensi dari izin itu sendiri yang melarang seseorang atau suatu badan hukum tertentu melakukan suatu kegiatan dan/atau usaha tanpa mendapatkan persetujuan/perkenan terlebih dahulu dari badan atau pejabat tata usaha negara yang berwenang. ${ }^{9}$

Perizinan mempunyai peranan yang vital, karena selain sebagai sumber PAD, perizinan juga sebagai instrumen perlindungan hukum atas kepemilikan atau penyelenggaraan kegiatan. Izin merupakan suatupersetujuandaripenguasaberdasarkan undang-undang atau peraturan pemerintah, untuk dalam keadaan tertentu menyimpang dari ketentuan-ketentuan larangan perundangan. ${ }^{10}$ Izin dalam arti luas berarti persetujuan dari penguasa berdasarkan peraturan perundang-undangan untuk memperbolehkan melakukan tindakan atau perbuatan tertentu yang secara umum dilarang. ${ }^{11}$

Ketentuan perizinan dalam Pasal 84 Perda Nomor 12 Tahun 2011 tentang RTRW Kota Mataram, yaitu:

\footnotetext{
${ }^{8}$ Y. Sri Pudyatmoko, Perizinan, Problem dan Upaya Pembanahan, Jakarta: PT. Grasindo, 2009, hlm. 10.

${ }^{9}$ NM Spelt dan JBJM Ten Berge, Pengantar Hukum Perizinan, disunting oleh Philipus M.Hadjon, Surabaya, Yuridika, 1993, hlm. 2.

${ }^{10} \mathrm{Ibid}, \mathrm{hlm} .2$

${ }^{11}$ Bagir Manan, Dalam Ridwan HR, Hukum Administrasi Negara, Edisi Revisi, Jakarta, Raja Grafindo Persada, 2010, hlm. 199.
}

(1) Ketentuan perizinan sebagaimana dimaksud dalam Pasal 52 ayat (2) huruf $b$ merupakan acuan bagi pejabat yang berwenang dalam pemberian izin pemanfaatan ruang berdasarkan rencana tata ruang yang ditetapkan dalam Peraturan Daerah ini.

(2) Ketentuan perizinan inibertujuan untuk:

a. Menjamin pemafaatan ruang sesuai dengan rencana tata ruang, peraturan zonasi, dan standar pelayanan minimal bidang penataan ruang;

b. Mencegah dampak negatif pemanfaatan ruang; dan

c. Melindungi kepentingan umum.

(3) Pemberian izin pemanfaatan ruang disertai dengan persyaratan teknis dan persyaratan administratif sesuai dengan ketentuan peraturan perundangundangan;

(4) Pemerintah Daerah melimpahkan kewenangan dalam penerbitan izin kepada Satuan Kerja Perangkat Daerah (SKPD) Kota yang membidangi perizinan.

Pasal 85 menjelaskan:

Izin pemanfaatan ruang sebagaimana dimaksud dalam Pasal 84 ayat (1) terdiri dari:

a. Izin prinsip;

b. Izin lokasi;

c. Izin pengguanaan dan pemanfaatan tanah; dan

d. Izin mendirikan bangunan

Pasal 86 menjelaskan:

(1) izin prinsip sebagimana dimaksud Pasal 85 huruf a diberikan berdasarkan rencana tata ruang wilayah kota bagi orangdan/ataubadanhukumyangakan melakukan pemanfaatan lahah; 
Baiq Burdatun| Penegakan Hukum Terhadap Alih Fungsi Lahan Pertanian Menjadi Lahan.

(2) ketentuan izin prinsip diatur lebih lanjut dengan Peraturan Walikota.

Pasal 87 menjelaskan:

(1) izin lokasi sebagimana dimaksud dalam Pasal 85 huruf b diberikan berdasarkanrencanatataruangwilayah kotabagi orang dan/ataubadan hukum yang akan melakukan pemanfaatan lahansetelahmendapatkanizinprinsip;

(2) ketentuan izin lokasi diatur lebih lanjut dengan Perturan Walikota.

Pasal 88 menjelaskan:

(1) izin penggunaan pemanfaatan tanah sebagaimana dimaksud dalam Pasal 85 huruf c diberikan berdasarkan izin lokasi;

(2) ketentuan izin penggunaan pemanfaatan tanah diatur lebih lanjut dengan Peraturan Walikota.

Pasal 89 menjelaskan:

(1) setiap orang dan/atau badan hukum yang akan melaksanakan pembangunanfisik harus memilikiizin mendirikan bangunan;

(2) izin mendirikan bangunan sebagaimanadimaksudpadaayat(1)diberikan berdasarkan Keterangan Rencana Kota;

(3) ketentuanizin mendirikanbangunan diatur lebih lanjut dengan Peraturan Walikota.

Yang dimaksud dengan izin prinsip berdasarkan penjelasan adalah surat izin yang diberikan oleh Pemerintah/pemerintah daerah untuk menyatakan suatu kegiatan secara prinsip diperkenankan untuk diselenggarakan atau beroperasi. Izin prinsip merupakan pertimbangan pemanfaatan lahan berdasarkan aspek teknis, politis, dan sosial budaya sebagai dasar dalam pemberian izin lokasi. Izin prinsip dapat berupa surat penunjukan penggunaan lahan.

Yang dimaksud dengan izin lokasi adalah izin yang diberikan kepada pemohon untuk memperoleh ruang yang diperlukan dalam rangka melakukan aktivitas nya. Izin lokasi merupakan dasar untuk melakukan pembebasan lahan dalam rangka pemanfaatan ruang. Izin lokasi diperlukan untuk pemanfaatan ruang untuk lebih dari 1 (satu) Hektar untuk kegiatan bukan pertanian dan lebih dari 25 (dua puluh lima) Hektar untuk kegiatan pertanian.

Izin penggunaan pemanfaatan tanah merupakan dasar untuk pemohon mendirikan bangunan. Dan izin mendirikan bangunan merupakan dasar dalam mendirikan bangunan dalam rangka pemanfaatan ruang.

Adapun persyaratan harus memenuhi syarat administrasi dan syarat teknis. Syarat administrasi bagi pemohon perorangan meliputi:

a) Identitas pemohon;

b) Nomor pokok wajib pajak; dan/atau

c) Sertifikasi keahlian.

Persyaratan administrasi bagi pemohon badan usaha dan koperasi meliputi:

a) Akte pendirian badan usaha;

b) Surat izin usaha perdagangan;

c) Nomor pokok wajib pajak;

d) Surat keterangan kepemilikan modal atau referensi bank;

e) Profile perusahaan; dan

f) Rencana kegiatan usaha jasa yang akan dilakukan.

Berdasarkan uraian tersebut izin alih fungsi lahan diterbitkan diawali dengan adanya permohonan tertulis yang disertai pemenuhan syarat izin usaha oleh 
pemrakarsa usaha. Kemudian dilanjutkan dengan pemeriksaan dan penilaian permohonan, penilaian pertama ialah penilaian untuk memperoleh persetujuan prinsipyaitudilakukanterhadappemenuhan persyaratan sebagaimana dimaksud di atas. Selanjutnya setelah memperoleh persetujuan prinsip pemohon dibebankan kewajibannya setelah itu Walikota sesuai kewenangannya memberikan izin alih fungsi lahan pertanian untuk kegiatan non pertanian.

Menyadari adanya potensi dampak negatif yang mungkin dapat ditimbulkan dari alih fungsi lahan pertanian terhadap lingkungan hidup, begitu pula lingkungan yang tidak bisa begitu saja merehabilitasi dirinya sendiri, maka diperlukan upaya pengendalian terhadap usaha dan/atau kegiatan yang dapat menimbulkan pencemaran dan/atau kerusakan lingkungan salah satunya adalah dengan mendayagunakan instrumen hukum administrasi negara berupa izin.

Salah satu upaya Pemerintah kota mataram dalam mencegah arus konversi lahan pertanian adalah dengan memperketat pemberian izin alih fungsi lahan. Dalam Peraturan Walikota Mataram Nomor 12 Tahun 2011 tentang Rencana Tata Ruang Wilayah (RTRW) Kota Mataram Tahun 2011-2030 diatur mengenai pengendalian pemanfaatan ruang dan wilayah. Salah satu bentuk pengendalian tersebut adalah mengenai peraturan zonasi. Ketentuan umum peraturan zonasi untuk kawasan pertanian meliputi:

a. Dilaranguntukaktivitasbudidayayang mengurangiluaskawasan sawahirigasi teknis dan setengah teknis;

b. Dilaranguntukaktivitasbudidayayang mengurangi atau merusak fungsi lahan dan kualitas tanah untuk pertanian;

c. Diizinkan untuk aktivitas pendukung pertanian; dan d. Diizinkan mendirikan rumah tinggal dengan syarat tidak mengganggufungsi pertanian.

Namun larangan konversi lahan pertanian tampaknya tak berjalan sesuai rencana. Meskipun sudah diatur dalam peraturan perundang-undangan, larangan konversi lahan tetap sulit dijalankan. Lahan pertanian tetap saja berubah jadi kompleks perumahan atau lokasi gedung perkantoran.

Terkait rencana Perda Kota Mataram yang akan membentuk Perda PLP2B di pending bahkan tidak ada raperda lagi. Rencana itu kini hanya sebatas angan-angan, karena melihat kepemilikan lahan pertanian di kota Mataram adalah para pengusaha atau pengembang. Petani di Kota Mataram hanya petani penggarap yang menyewa di tuan tanah selama 2 tahun atau lebih. Oleh sebab itu alasan para petani tidak mau menerima bantuan permanen dari pemerintah karena lahan pertanian itu bukan miliknya. Contohnya petani tidak mau menerima bantuan pupuk organik karena dirasa pupuk organik tidak memberikan hasil pertanian secara langsung akan tetapi setahun atau dua tahun kemudian, sementara petani mengejar omset atau untung dari hasil pertanian nya, sehingga petani banyak menggunakan pupuk kimia, karena saling berkejaran dengan waktu sewa sawah nya. Oleh sebab itu, upaya pemerintah dalam hal ini pemerintah dinas pertanian Kota Mataram mulai melakukan pendekatan dengan para petani dimana lahan yang 1 (satu) hektar dihimbau agar ada sepetak untuk tanaman hortikultura. Yang menjadi kendala pemerintah dalam mendekati para petani supaya mau menanam tanaman hortikultura adalah: kebanyakan petani kita ingin santai. Petani tidak mau ambil resiko, karena kalau tanaman padi bisa diperiksa sekali seminggu sedangkan tanaman hortikultura harus benar-benar serius diperhatikan setiap hari. Sulit bagi pemerintah mencari petani yang sungguhsungguh mau mendukung kebijakan 
pemerintah dalam upaya peningkatan dan pengembangan tanaman hortikultura.

Sehingga dengan banyaknya alih fungsi lahan di Kota Mataram banyak petani yang beralih profesi, menjadi tukang bangunan, buruh serabutan, bahkan menganggur. Itulah salah satu resiko dari kota metropolis harus kehilangan lahan pertanian. Dan arah kebijakan RTRW pun mulai berubah dimana melindungi lahan pertanian berubah menjadi kota metropolis yang bergerak di bidang jasa, perdagangan, transportasi, perkantoran dan pendidikan

\section{Penegakan Hukum Terhadap Alih Fungsi Lahan Pertanian Menjadi La- han Non Pertanian Di Kota Mataram}

Penegakan hukum adalah potensi dilakukannya upaya untuk tegaknya atau berfungsinya norma-norma hukum secara nyata sebagai pedoman prilaku dalam lalu lintas atau hubungan-hubungan hukum dalam kehidupan bermasyarakat dan bernegara. Dalam artiluas, proses penegakan hukum itu melibatkan semua subjek hukum dalam setiap hubungan hukum. Dalam arti sempit, dari segi subjeknya itu, penegakan hukum itu hanya diartikan sebagai upaya aparatur penegakan hukum tertentu untuk menjamin dan memastikan bahwa suatu aturan hukum berjalan sebagaimana seharusnya. Dalam memastikan tegaknya hukum itu, apabila diperlukan, aparatur penegak hukum itu diperkenankan untuk menggunakan daya paksa. ${ }^{12}$

Terkait dengan penegakan hukum alih fungsi lahan pertanian Pemerintah pusat maupun pemda masih menganggap bahwa pembangunan hanya semata-mata mendorong peningkatan infrastruktur fisik, yang seringkali mengorbankan lahan pertanian produktif. Alih fungsi lahan pertanian menjadi pemukiman penduduk, pembangunan infrastruktur publik serta

12 Jimly Assihidiqie, makalah Penegakan Hukum, www.jimly.com, diakses tanggal 10 Agustus 2016 sarana industri cukup mengkhawatirkan sehingga akan berdampak terhadap krisis pangan secara nasional maupun regional apabila tidak ditangani secara serius. Di tengah target swasembada pangan tahun 2017, perlu ada langkah serius dalam penegakan hukum dan proteksi maksimal terhadap lahan pertanian produktif.

Alih fungsi lahan pertanian menjadi non pertanian dapat mempengaruhi berbagai aspek kehidupan, antara lain menurunnya produksi pangan yang menyebabkan terancam nya kedaulatan pangan, hilangnya mata pencaharian petani dan dapat menimbulkan pengangguran, dan hilangnya investasi infrastruktur pertanian (irigasi) yang menelan biaya yang sangat tinggi.

Sudah banyak regulasi yang sudah dikeluarkan, namun komitmen dalam penerapannya sangat minim dari Pemerintah maupun Pemda. UndangUndang Nomor 1 Tahun 2009 tentang PLP2B dilengkapi dengan peraturan pemerintah daerah. Regulasi-regulasi tersebut dalam implementasinya belum efektif sebagaimana terlihat dari alih fungsi lahan pertanian yang terus terjadi dan semakin tidak terkendali. Insentif ekonomi yang tertuang dalam peraturan pemerintah tersebut masih dalam tataran normatif, sehingga relatif sulit untuk diimplementasikan di lapangan.

Jika dilihat secara cermat, maka terdapat 3 komponen yang terlibat dalam hal alih fungsi lahan yaitu Pemerintah, investor dan masyarakat, jika dilihat dari kaca mata teori prismatik yang dikemukakan oleh Mahfud MD, maka pemerintah dihadapkan pada dua kepentingan yaitu kepentingan kelompok dan kepentingan individu.

Menurut Mahfud MD:

"Watak hukum yang akan mempengaruhi politik hukum suatu negara akan sangat ditentukan oleh pilihan nilai kepentin- 
gan, yakni apakah mementingkan kemakmuran perseorangan ataukah akan mementingkan kemakmuran banyak orang. Pembedaan atas banyak atau sedikitnya pemenuhan kepentingan itu didasarkan pada perspektif ekonomi politik. Sementara itu dari perspektif teori sosial, bahkan dari sudut perspektif ideologi, pembedaan kepentingan itu didikotomikan atas paham individualisme-liberal (menekankan kebebasan individu) atau kapitalisme dan kolektivisme atau komunisme (yang menekankan kepentingan bersama)."13

Apabila kita menilik teorinya Lawrence M. Friedman, terdapat 3 (tiga) faktor yang sangat mempengaruhi dalam penegakan hukum, yaitu sebagai berikut: a) Legal Substance atau substansi hukum; b) Legal Structure atau Struktur hukum, di dalamnya termasuk kelembagaan nya; c) Legal Culture atau budaya hukum. Teori dari Friedman tersebut dapat dijadikan sebagai parameter mengapa penegakan hukum di Indonesia, dalam hal pengendalian alih fungsi tanah pertanian tidak berjalan secara efektif.

Efektifitas hukum ditunjukkan oleh pilihan menggunakan hukum yang bergantung pada tingkat kepatuhan masyarakatnya. Hukum akan menjadi efektifjika orang benar-benar berbuat sesuai dengan norma-norma hukum sebagaimana mereka harus berbuat, bahwa normanorma itu benar diterapkan dan dipatuhi. Di indonesia, kepatuhan terhadap hukum bergantung seberapa besar hukum itu valid dan diimani oleh masyarakat sebagai kekuatan hukum yang mengikat prilaku mereka. salah satu yang mempengaruhi penegakan hukum khususnya masalah alih fungsi lahan adalah terkait legal structure atau struktur hukum, hal ini terjadi karena kurang adanya koordinasi dan konsolidasi antar lembaga/instansi terkait dalam

${ }^{13}$ Mahfud MD. Membangun Politik Hukum Menegakkan Konstitusi, Jakarta, PT Raja Grapindo Persada, 2011, hlm. 23-24. melakukan kebijakan pengendalian alih fungsi lahan pertanian ke nonpertanian. Selain itu kurangnya pemahaman diantara para penegak hukum yang terkait dengan bidang agraria terkait Pasal 33 ayat 3 UUD 1945 Juncto Pasal 2 UUPA dimana ditekankan bahwa seluruh kekayaan alam di Indonesia baik itu yang ada bumi, air dan ruang angkasa dipergunakan sebesar-besarnya kemakmuran rakyat. Karena kurang pemahaman terhadap aturan tersebut, sehingga pemerintah atau aparat penegak hukum bidang agraria dengan mudah memberikan izin untuk melakukan alih fungsi lahan pertanian dengan dalih meningkatkan PAD dan kepentingan sekelompok orang tampa memperhatikan kepentingan masyarakat kecil dan tidak peduli terhadap lahan pertanian berkelanjutan. Sehingga tidak mengherankan Negara kita yang subur, hijau ranau dan terkenal dengan semboyan "Gemah Ripah Loh Jenawi Tototentrem Kartoraharjo" menjadi pengimpor beras dan bahan pangan lainya dari luar negeri yang notabene potensi sumber daya pertaniannya jauh di bawah Indonesia.

Posisi penegak hukum sangat vital dalam pelaksanaan suatu aturan hukum, bahkan sekalipun aturan hukumnya kurang baik asalkan penegak hukumnya baik, maka hal itu masih bisa diatasi. Namun sebaik apapun aturan hukum yang ada, bila penegak hukumnya tidak memiliki kapasitas dan kapabilitas yang bagus,dalam arti rendahnya intelektualitas, moralitas, spiritualitas, maka hukum yang baik itu tidak ada gunanya.

Pemerintah daerah kota Mataram menyampaikan sangat sulit sekali menegakkan hukum terkait dengan alih fungsi lahan pertanian karena kembali lagi pada pembahasan sebelumnya bahwa, tanah pertanian di kota Mataram ini sebagian besar telah dikuasai oleh pengusaha ataupun pengembang. Sehingga banyak terjadinya carut marut terhadap 
pelanggaran tata ruang kota. Di samping itu juga, masyarakat tidak mengetahui substansi daripada perda RTRW kota Mataram. Hal ini disebabkan karena kurangnya sosialisasi yang dilakukan oleh pemda baik itu oleh Bappeda Kota Mataram, dinas Pertanian dan DPRD Kota Mataram.

Jika penulis kembali pada keterangan informan-informan sebelumnya, yaitu Kasubag dinas pertanian kota Mataram yang menyampaikan bahwa penegakan hukum terkait alih fungsi lahan pertanian amat sangat lemah terutama dari dinas perizinan, padahal kami dari dinas pertanian telah memberikan rekomendasi agar pemkot selektif dalam memberikan izin ataupun eksekusi lahan pertanian mengingat tinggal sedikitnya lahan pertanian di kota Mataram. Sementara di lain pihak yaitu pemda kota mataram menyimpulkan sebaliknya bahwa mereka telah melakukan penegakan hukum berdasarkan perda RTRW dan telah memberikan sanksi bagi yang melakukan pelanggaran. Namun yang menjadi kendala dalam penegakan hukumnya adalah penguasaan tanah pertanian yang dikuasai oleh tuan tanah atau pengusaha, sehingga tanah-tanah pertanian yang sudah di alih fungsikan sulit untuk dihentikan karena mengingat hak keperdataan seseorang sehingga diberikan lah pengecualian.

Oleh sebab itu adapun arah kebijakan yang akan dikeluarkan selanjutnya oleh Pemda Kota Mataram adalah dengan merevisi Perda RTRW Nomor 12 Tahun 2011 dengan pertimbangan juga bahwa konsekuensi dari kota metropolis adalah mau tidak mau kota harus siap kehilangan lahan pertanian.

Demikian juga halnya dengan keterangan anggota DPRD Kota Mataram menyampaikan bahwa "kami telah berpedoman kepada perda RTRW dan dalam upaya mengkonservasi lahan pertanian kami telah mengacu kepada Undang-undang tentang PLP2B, serta telah melakukan koordinasi antara pemda dan DPRD dalam hal alih fungsi lahan pertanian di kota Mataram ini."

Sementara pihak BPN Kota Mataram mengatakan penegakan hukum terkait alih fungsi lahan pertanian belum efektif karena banyaknya kendala baik menyangkut kurangnya kesadaran masyarakat akan dampak alih fungsi lahan pertanian namun mereka terus menerus melakukan alih fungsi baik secara alami (berkembang dengan sendirinya) maupun yang dilakukan oleh pengembang. Kurangnya sosialisasi perda RTRW kota Mataram yang seharusnya merupakan tanggungjawab semua leading sektor baik pemerintah daerah, dinas pertanian, badan penyuluhan pertanian dan DPRD.

\section{SIMPULAN}

1. Adapun bentuk kebijakan pemkot Mataram ditengah kondisi alih fungsi lahan pertanian yang semakin krodit ini, DPRD Kota Mataram bersama eksekutif akan melakukan revisi terhadap perda RTRW. rencana revisi perda RTRW bukan untuk mengesahkan pelanggaran yang sudah ada. Tapi bertujuan membangun tata ruang kota yang lebih baik, revisi dilakukan karena pemerintah juga mempertimbangkan kondisi di tengah masyarakat. Revisi RTRW yang akan dibuat ini diharapkan akan mengakomodasi, memproyeksikan persoalan yang akan dihadapi di masa depan. Hal ini akan menjadi dasar hukum bagi pemerintah untuk mengatur pembangunan. Jika tidak diatur, pemerintah sulit melarang pengusaha membangun.

2. Mekanism pelaksanaan Izin alih fungsi lahan diterbitkan diawali dengan adanya permohonan tertulis yang disertai pemenuhan syarat izin usaha oleh pemrakarsa usaha. Kemudian dilanjutkan dengan pemeriksaan dan 
penilaian permohonan, penilaian pertama ialah penilaian untuk memperoleh persetujuan prinsip yaitu dilakukan terhadap pemenuhan persyaratan sebagaimana dimaksud di atas. selanjutnya setelah memperoleh persetujuan prinsippemohon dibebankan kewajibannya, setelah itu Walikota sesuai kewenangannya memberikan izin alih fungsi lahan pertanian untuk kegiatan non pertanian. Pelaksanaan prosedur izin pemanfaatan ruang dilaksanakan oleh Kantor Pelayanan Terpadu dengan mempertimbangkan rekomendasi hasil forum koordinasi BKPRD. Ketentuan mengenai perizinan terdapat dalam Pasal 84 Perda Nomor 12 Tahun 2011 tentang RTRW Kota Mataram.

3. Penegakan hukum terhadap alih fungsi lahan pertanian menjadi lahan non pertanian di kota Mataram belum efektif karena dipengaruhi oleh faktor-faktor yuridis/hukum seperti legal substance, legal structure, legal culture. Faktor non yuridis atau non hukum seperti faktor ekonomi, faktor pemberlakuan Mataram sebagai pusat ekonomi dan jasa/ Mataram Metro, faktor kurang tegasnya penegak hukum, dan faktor pertumbuhan penduduk yang pesat, juga faktor-faktor sosial lainnya. Sehingga menurut penulis dariketeranganyangdidapatdaribeberapa informan, pemerintah sangat sulit menegakan aturan hukum terkait alih fungsi lahan pertanian menjadi lahan non pertanian disebabkan oleh kepemilikan tanah pertanian atau persawahan di kota Mataram dimiliki oleh tuan tanah atau para pengusaha, sementara petani di kota ini lebih banyak petani penggarap.

\section{DAFTAR PUSTAKA}

Achmad Sodiki dan Yanis Maladi, Politik Hukum Agraria, Yogyakarta: Mahkota Kata, 2009.

H. M. Arba, Hukum Tata Ruang dan Tata Guna Tanah, Prinsip-Prinsip
Hukum Perencanaan Penataan Ruang dan Penatagunaan Tanah, Cetakan II, Mataram: Pustaka Bangsa, 2015.

Jimly Assihidiqie, makalah Penegakan Hukum, www.jimly.com, diakses tanggal 10 Agustus 2016.

Lawrance M. Friedman, Sistem Hukum Perspektif Ilmu Sosial, Jakarta: Nusamedia, 1984.

Mahfud MD, Membangun Politik Hukum Menegakkan Konstitusi, Jakarta: PT Raja Grapindo Persada, 2011.

Mas Roro Liliek Ekawati, Perencanaan, Implementasi dan Evaluasi Kebijakan atau Program (Suatu Kajian Teoritis dan Praktis), Surakarta: Pustaka Cakra, 2005.

Mohan Roliskana, "Selamatkan RTH atau Karpet Merah Pengusaha," Lombok Post, 5 Agustus 2016.

NM Spelt dan JBJM Ten Berge, Pengantar Hukum Perizinan, disunting oleh Philipus M.Hadjon, Surabaya: Yuridika, 1993.

Ridwan HR, Hukum Administrasi Negara, Edisi Revisi, Jakarta: Raja Grafindo Persada, 2010.

Soerjono Soekanto, Faktor-faktor yang Mempengaruhi Penegakan Hukum, Jakarta: PT RajaGrafindo Persada, 2011.

Y. Sri Pudyatmoko, Perizinan, Problem dan Upaya Pembanahan, Jakarta: PT. Grasindo, 2009. 